\title{
Keterampilan Pengisian Partograf pada Mahasiswa Akademi Kebidanan di Wilayah Kota Jakarta Timur tahun 2015
}

\author{
Aan Rosanti*), Sutopo Patria Jati **), Syamsulhuda BM**) \\ *) Akademi Kebidanan Prestasi Agung \\ Email : rosanti@ymail.com \\ **) Fakultas Kesehatan Masyarakat Universitas Diponegoro Semarang
}

\begin{abstract}
ABSTRAK
Partograf merupakan panduan pengelolaan dan observasi persalinan normal yang akan memudahkan penolong persalinan dalam mendeteksi kasus kegawatdaruratan pada ibu dan janin. Partograf memegang peranan penting dalam menentukan diagnosa persalinan. Jenis penelitian yang digunakan adalah penelitian observasional rancangan cross sectional. Data diperoleh dari sumbernya menggunakan lembar observasi dan kuesioner. Lokasi penelitian ini kampus Akademi Kebidanan yang berada di wilayah Jakarta Timur. Subyek penelitian adalah seluruh mahasiswa yang sudah belajar partograf dan sudah praktik pertolongan persalinan, jumlah sampel 201 mahasiswa bidan berdasarkan kriteria inklusi. Analisis hasil penelitian dengan menggunakan uji Chi square dan regresi logistic multipel. Hasil penelitian menunjukkan keterampilan penggunaan partograf baik $(56,7 \%)$, umur mahasiswa sebagian besar $\geq 20$ tahun $(58,7 \%)$, motivasi mahasiswa tinggi $(57,7 \%)$, persepsi mahasiswa terhadap proses pembelajaran baik $(52,2 \%)$, persepsi mahasiswa terhadap fasilitas pendidian baik $(52,75)$. Adanya hubungan antara motivasi mahasiswa $(\mathrm{p}=0,005)$ dengan keterampilan pengisian partograf dan tidak adanya hubungan antara umur, persepsi proses pembelajaran dan persepsi fasilitas pendidikan dengan keterampilan pengisian partograf. Hasil dari uji regresi menunjukkan adanya pengaruh motivasi dengan pengisian partograf ( $p$ value $=0,004$, $\exp B$ 2,350). Rekomendasi dari penelitian ini bagi semua mahasiswa bidan yang praktek di ruang bersalin wajib menggunakan partoraf dalam setiap pertolongan persalinan. Bagi institusi kebidanan untuk meningkatkan kerja sama dengan CI lahan praktek dalam memberikan bimbingan dan memonitor laporan persalinan mahasiswanya.
\end{abstract}

Kata Kunci: Keterampilan pengisisan partograf, motivasi, proses pembelajaran, fasilitas pendidikan.

\begin{abstract}
Factors associated with Partograph Charging Skills in Student Midwife Academy in East Jakarta. Partographs an observation management guidelines and normal deliveries which will facilitate birth attendants in detecting emergency cases in the mother and fetus. Partographs plays an important role in determining the diagnosis of labor. This type of research is observational cross-sectional design. Data obtained from the source using observation sheets and questionnaires. The location of this study Midwifery Academy campus located in East Jakarta. Subjects were all students who have already studied partograf and aid delivery practices, the number of samples 201 student midwives based on inclusion criteria. Analysis of the results using the chi square test and multiple logistic regression. The results showed good skills partograf use (56.7\%), most of the students age $\geq 20$ years (58.7\%), high student motivation (57.7\%), students' perceptions of the learning process both $(52.2 \%)$, students' perceptions of good pendidian facilities (52.75). The relationship between student motivation ( $p=0.005$ ) with the charging partograf skills and no correlation between age, the perception of the learning process and perceptions of educational facilities with charging partograf skills. Results of regression test showed the influence of motivation by charging partograf ( $p$ value $=0.004, \beta$ exp 2,350). Recommendations from this study for all
\end{abstract}


student midwives who practice in the delivery room must use partoraf in every delivery assistance. For midwifery institutions to enhance cooperation with land CI practice in providing guidance and monitoring the delivery report students.

Keywords: Skills filling partograf, motivation, learning, education facilities.

\section{PENDAHULUAN}

Angka Kematian Ibu (AKI) dan Angka kematian Bayi (AKB) merupakan salah satu indikator yang sering digunakan untuk menilai derajat kesehatan suatu bangsa atau negara. Kematian ibu di latarbelakangi oleh terlambat mengenal tanda bahaya dan mengambil keputusan, terlambat mencapai fasilitas kesehatan, serta terlambat mendapatkan pelayanan di fasilitas kesehatan. Hasil Survei Demografi Kesehatan Indonesia (SDKI) menunjukan Angka Kematian Ibu (AKI) tahun 2002 mencapai 307 per 100.000 kelahiran hidup (KH) dan terjadi penurunan AKI di tahun 2007 sebesar 228 per 100.000 KH. Namun angka tersebut masih jauh dari yang diharapkan untuk mencapai target MDGs (Millenium Development Goals) tahun 2015 yaitu 102 per 100.000 kelahiran hidup. Kasus kematian maternal disebabkan oleh komplikasi perdarahan (30\%), preeklampsia/ eklampsia (25\%), infeksi (12\%), komplikasi nifas (8\%) dan penyebab lainnya (15\%). (BKKBN, 2012)

Deteksi dini komplikasi persalinan merupakan salah satu penerapan peran dan fungsi bidan sebagai pelaksana. Untuk itu kompetensi bidan yang meliputi pendidikan, pengetahuan dan keterampilan harus dimiliki oleh bidan dalam melaksanakan praktik kebidanan secara aman dan bertanggung jawab pada berbagai tatanan pelayanan kesehatan. Bidan sebagai pemberi pelayanan terdepan dalam pelayanan KIA dan KB perlu ditingkatkan kualitas pelayanan kebidanan sehingga mampu mencapai target dan standar yang diharapkan. Bidan dituntut memiliki kemampuan mendeteksi komplikasi sedini mungkin agar dapat segera melakukan tindakan dan rujukan. Ketika komplikasi tidak dapat dihindarkan, maka bidan dapat memberikan pertolongan pertama secara cepat dan tepat serta merujuk pasien secara efektif (tepat waktu dan menstabilkan pasien). (PP IBI, 2006)

Upaya Kemenkes dalam pengaturan penyelenggaraan izin praktik bidan telah diterbitkan dalam Peraturan Menteri Kesehatan Republik Indonesia Nomor 1464/Menkes/Per/X/2010 tentang izin dan penyelenggaraan praktik bidan. Bidan berwenang memberikan pelayanan kesehatan pada ibu dan anak dalam menjalankan praktiknya serta wajib mematuhi standar pelayanan kebidanan serta senantiasa meningkatkan mutu 
pelayanan profesinya dengan mengikuti perkembangan IPTeks melalui pendidikan dan pelatihan sesuai dengan bidang tugasnya. Hal ini didukung pula oleh KepMenKes No. 369/Menkes/SK/III/2007 tentang Standar Profesi Kebidanan bahwa ruang lingkup dalam pelayanan kebidanan berfokus pada upaya pencegahan, promosi kesehatan, pertolongan persalinan normal, deteksi komplikasi pada ibu dan anak, melaksanakan tindakan asuhan sesuai dengan kewenangan atau bantuan lain jika diperlukan, serta melaksanakan tindakan kegawatdaruratan. (PP IBI, 2006)

Kompetensi ke- 4 menyebutkan bahwa salah satu keterampilan dasar Bidan adalah melakukan pemantauan kemajuan persalinan dengan menggunakan partograf. Partograf merupakan salah satu alat bantu untuk memantau kemajuan atau observasi persalinan di kala I yang akan memudahkan penolong persalinan dalam mendeteksi dini penyulit persalinan sehingga keterlambatan dalam pengambilan keputusan klinik atau rujukan pada ibu dan bayi. dapat dihindari. (PP IBI, 2006)

Bidan yang kompeten diawali dari proses pendidikan yang baik dimana calon bidan/ peserta didik tidak hanya mendapatkan pendidikan dikelas dalam bentuk kuliah, seminar dan diskusi, tetapi juga proses pembeljaran klinik yang dilakukan di laboratorium dan lahan tempat praktik. Proses belajar mengajar merupakan suatu kegiatan dalam rangka melaksanakan kurikulum suatu lembaga pendidikan agar dapat mencapai tujuan pendidikan yang telah ditetapkan. (Pusdiknakes Kemenkes RI, 2011)

Pendidikan adalah suatu usaha atau kegiatan yang dijalankan dengan sengaja, teratur dan terencana dengan maksud mengubah atau mengembangkan perilaku sesuai dengan tujuannya. Menurut UU No. 20 Tahun 2003 tentang Sistem Pendidikan Nasional, pendidikan adalah usaha sadar dan terencana untuk mewujudkan suasana belajar dan proses pembelajaran agar peserta didik secara aktif mengembangkan potensi dirinya untuk memiliki kekuatan spiritual keagamaan, pengendalian diri, kepribadian, kecerdasan, akhlak mulia, serta keterampilan yang diperlukan dirinya, masyarakat, bangsa dan negara. (Pusdiknakes RI, 2011)

Keinginan menciptakan lulusan terbaik dan dapat diterima di dunia kerja dan dalam masyarakat merupakan keinginan setiap perguruan tinggi. Lulusan yang baik dan dapat diterima di dunia kerja akan sangat sulit tercapai mengingat saat ini banyak perguruan tinggi yang hanya mementingkan hard skill dan kurang memperhatikan soft skill. Padahal soft skill menjadi syarat mutlak untuk masuk ke 
dunia kerja dan sangat diperlukan mahasiswa dalam menghadapi kehidupan di masyarakat. Hal ini bukan berarti hard skill tidak di butuhkan, tetapi keduanya harus berjalan bersamaan. Dengan soft skill yang baik, mahasiswa akan terampil dalam berkomunikasi, memimpin, membina hubungan dengan orang lain dan mengembangkan diri. Sedangkan hard skill akan sangat dibutuhkan ketika mahasiswa baru memasuki dunia kerja (Elfindri, 2009)

Proses belajar mengajar suatu pendidikan dapat berjalan dengan lancar dan baik bila di tunjang dengan input yang baik sehingga menghasilkan output yang berkualitas. Input adalah bahan mentah yang dimasukkan kedalam proses. Dalam pendidikan yang dimaksud dengan input adalah calon siswa yang baru akan memasuki sekolah, sebelum memasuki suatu tingkat sekolah (institusi) calon siswa tersebut dinilai dahulu kemampuannya. Dengan penilaian itu ingin diketahui apakah kelak ia akan mampu mengikuti pelajaran dan melaksanakan tugas- tugas yang akan diberikan kepadanya, serta input/ masukan pendukung lainnya yaitu input instrumental dan lingkungan. Input instrumental terdiri dari guru, materi, sarana pendidikan dan pengelolaan, manajemen atau pengaturan dan input lingkungan bisa berupa benda, alam maupun manusia.(Kemenkes RI, 2011)

Provinsi DKI Jakarta, memiliki sekitar 31 pendidikan bidan yang tersebar di lima wilayah kota yaitu di Kota Jakarta Utara memiliki 1 institusi pendidikan bidan, Jakarta Timur memiliki 15 (lima belas) pendidikan bidan, Jakarta Pusat memiliki 8 (delapan) pendidikan bidan, Jakarta Selatan memiliki 6 (enam) Akbid dan Jakarta Barat memiliki 1 (satu) Akbid. (Kemenkes RI, 2012)

Pendidikan Diploma III kebidanan memiliki kurikulum pembelajaran dengan rasio teori sebanyak $40 \%$ dan praktek sebanyak $60 \% .{ }^{10}$ Mata kuliah wajib diantaranya Asuhan Kebidanan Persalinan (Askeb II) dengan bobot 4 SKS penempatannya di semester III dengan salah satu sub pokok bahasannya adalah pembelajaran partograf. Pembelajaran partograf di berikan secara teori dan praktik dalam kelas maupun laboratorium dan penerapannya pada asuhan persalinan saat praktik klinik di Rumah Bersalin/ Bidan Praktik Mandiri, Puskesmas, ataupun Rumah Sakit. (Kemenkes RI, 2002)

Pengisian partograf merupakan hal yang sangat penting, namun dalam prakteknya masih belum sempurna dilaksanakan oleh bidan, seperti disebutkan dalam penelitian sultina bahwa 
pada status ibu bersalin dari bulan JanuariJuni 2010 pada catatan medik RSUD Provinsi Sulawesi Tenggara dari 426 total persalinan terdapat $259(60,8 \%)$ kasus yang tidak menggunakan partograf, 53 $(12,4 \%)$ kasus persalinan menggunakan partograf dan pengisiannya tidak lengkap, dan $114(26,8 \%)$ kasus persalinan yang menggunakan partograf yang pengisiannya lengkap dan tepat. (Bekti, 2011)

Output pendidikan dapat dilihat dari hasil belajar siswanya yang dapat berupa pengetahuan, keterampilan dan prestasi hasil belajar. Keterampilan calon bidan/ mahasiswa bidan diantaranya dapat melakukan pengisian partograf dengan benar, lengkap dan tepat dalam upaya melakukan deteksi dini komplikasi yang mungkin terjadi pada ibu saat persalinan sehingga pengambilan keputusan yang tepat dalam penanganan persalinan maupun dalam rujukan mampu menyelamatkan ibu dan bayi yang secara tidak langsung membantu program pemerintah untuk mencapai target MDGs (Millenium Development Goals) tahun 2015 yaitu Angka Kematian Ibu 102 per 100.000 kelahiran hidup.

Pada penelusuran hasil dokumentasi laporan praktik klinik kebidanan di perpustakaan Akademi Kebidanan Prestasi Agung Jakarta tahun 2014 dari total 114 laporan persalinan, terdapat $54(47,36 \%)$ laporan persalinan yang tidak menggunakan partograf. Padahal sebelumnya mahasiswa sudah mendapat pembelajaran dan latihan tentang pengisian partograf. Pencapaian ini masih jauh dari harapan karena apabila penolong persalinan tidak mampu melakukan pemantauan kemajuan persalinan dengan menggunakan partograf dapat menyebabkan resiko kegawatdaruratan obstetric yang lebih buruk sehingga meningkatkan angka kematian ibu (AKI) dan angka kematian bayi (AKB). (Akbid, 2012)

Berdasarkan uraian tersebut maka peneliti ingin melakukan penilaian keterampilan pengisian partograf dan mengetahui faktor-faktor yang berhubungan dengan keterampilan pengisian partograf pada mahasiswa Akbid di Jakarta Timur.

\section{METODE}

Penelitian ini merupakan penelitian kuantitatif dengan pendekatan studi potong lintang (cross sectional study), yaitu suatu pendekatan yang sifatnya sesaat pada suatu waktu dan tidak diikuti terus menerus dalam kurun waktu tertentu. (Notoatmodjo,2010). Populasi dalam penelitian ini adalah mahasiswa yang telah belajar partograf pada Akademi Kebidanan yang tergabung dalam Asosiasi Institusi 
Pendidikan Kebidanan Indonesia (AIPKIND) dan sudah terakreditasi BANPT di Jakarta Timur yang berjumlah 420 mahasiswa. Pengambilan sampel dilakukan dengan teknik proporsional random sampling, sehingga diperoleh jumlah sampel sebanyak 201 responden yang terdiri dari 5 (lima) Akademi Kebidanan di Jakarta Timur. Untuk membuktikan keabsahan kuesioner yang digunakan dalam penelitian ini perlu dilakukan uji coba kuesioner pada mahasiswa tingkat II dan III Akademi Kebidanan Prestasi Agung Jakarta Timur yang berjumlah 40 mahasiswa. Uji validitas dilakukan dengan uji korelasi product moment, sedangkan uji reliabilitas menggunakan uji statistik alpha cronbach. Analisis data yang digunakan adalah analisis univariat, bivariat dengan chi square dan multivariat dengan regresi logistik.

\section{HASIL DAN PEMBAHASAN}

\section{Gambaran Umum Lokasi Penelitian}

Pemerintah Kota Administrasi Jakarta Timur merupakan salah satu wilayah administrasi di bawah Pemerintah Provinsi DKI Jakarta. Secara geografis letak Kota Administrasi Jakarta Timur pada posisi antara $106^{0} 49^{\prime} 35^{\prime}$, Bujur Timur dan 06 10 '37', Lintang Selatan. Luas wilayah Kota Administrasi Jakarta Timur mencapai $188,42 \mathrm{Km} 2$ atau mencapai $28,39 \%$ dari luas total wilayah Provinsi DKI Jakarta. Dari luas ini sebagian besar terdiri dari dataran rendah dan dibagi ke dalam 10 Kecamatan, yaitu Kecamatan Pasar Rebo, Ciracas, Cipayung, Makasar, Kramatjati, Jatinegara, Duren Sawit, Cakung, Pulogadung dan Matraman. Adapun jumlah kelurahan di Kota Administrasi Jakarta Timur adalah 65 kelurahan.

Wilayah Kota Administrasi Jakarta Timur memiliki perbatasan sebelah utara dengan Kota Administrasi Jakarta Utara dan Jakarta Pusat, sebelah timur dengan Kota Bekasi (Provinsi Jawa Barat), sebelah selatan Kabupaten Bogor (Provinsi Jawa Barat) dan sebelah barat dengan Kota Administrasi Jakarta Selatan dan terdiri dari $95 \%$ daratan dan selebihnya rawa atau persawahan dengan ketinggian ratarata 50 meter dari permukaan air laut. Kota Administrasi Jakarta Timur Jakarta Timur dilalui oleh 7 (tujuh) sungai/kali yaitu Kali Ciliwung, Kali Sunter, Kalimalang, Kali Cipinang, Kali Buaran, Kali Jatikramat dan Kali Cakung. (Biro Pusat Statistik, Provinsi DKI Jakarta, 2012)

\section{Keterampilan pengisian partograf}

Berdasarkan hasil penelitian menunjukkan bahwa keterampilan pengisian partograf pada mahasiswa Akademi Kebidanan di Jakarta Timur 
sebagian besar $(56,7 \%)$ mahasiswa sudah baik keterampilannya dalam mengisi partograf dan hanya $(43,3 \%)$ responden yang masih kurang terampil dalam mengisi partograf.

Tingginya persentase mahasiswa yang mengisi partograf dengan baik, mengindikasikan bahwa pendokumentasian asuhan kebidanan ibu bersalin sudah cukup baik, sehingga hal ini dapat membantu mendeteksi dini terhadap kasus- kasus kebidanan khususnya persalinan yang mengarah pada abnormal dapat di tangani dengan baik, sehingga di harapkan selesai dari menempuh pendidikan mahasiswa bidan dan menjadi bidan sudah terampil dalam mengisi partograf.

Mahasiswa harus mempraktekan atau melakukan keterampilan pengisian partograf, kemudian pengajar atau pembimbing perlu memberikan umpan balik terhadap keterampilan yang telah dikerjakan dengan tujuan peserta didik mengetahui apakah keterampilan yang dilakukan tersebut sudah benar, atau masih ada kekurangannya. Umpan balik ini dapat berasal dari dosen, dari teman- temannya atau dapat berasal dari mahasiswa itu sendiri

Pengisian lembar partograf dengan cara setiap responden diberikan dua contoh soal kasus persalinan yang sama untuk setiap responden yang dimulai dari kala I pembukaan $4 \mathrm{~cm}$ dan pembukaan $5 \mathrm{~cm}$, kemudian data yang ada dalam kasus persalinan tersebut di catat dan diisikan ke dalam kolom partograf yang sesuai dengan ketentuan pengisiannya. Sebagian besar responden sudah mengisi partograf dengan benar, tetapi masih ada yang prosentase kesalahannya cukup besar yaitu $(46,8 \%)$ tidak benar mengisikan baik tempat mencatat maupun simbol penyusupan sutura kepala janin (molage) ke dalam partograf dengan simbol yang sesuai dengan kasus persalinan yaitu dengan lambang- lambang (0) apabila tulangtulang kepala janin terpisah, sutura dengan mudah dapat di palpasi: (1) apabila tulangtulang kepala janin hanya saling bersentuhan; (2) apabila tulang- tulang kepala janin saling tumpang tindih tetapi masih dapat dipisahkan dan (3) apabila tulang- tulang kepala janin saling tumpang tindih dan tidak dapat dipisahkan.

Penyusupan adalah indikator penting tentang seberapa jauh kepala bayi dapat menyesuaikan diri terhadap bagian keras (tulang) panggul ibu. Semakin besar derajat penyusupan atau tumpang tindih antar tulang kepala semakin menunjukan resiko disproporsi kepala panggul (CPD). Ketidakmampuan untuk berakomodasi atau disproporsi ditunjukan melalui derajat penyusupan atau tumpang tindih (molase) 
yang berat sehingga tulang kepala yang saling menyusup, sulit untuk dipisahkan. Apabila ada dugaan disproporsi kepala panggul maka penting untuk memantau kondisi janin serta kemajuan persalinan. Lakukan tindakan pertolongan awal yang sesuai dan rujuk ibu dengan dugaan proporsi kepala panggul (CPD) ke fasilitas kesehatan.

Pencatatan kolom tanda tangan penolong sebesar $39,3 \%$ masih salah mengisinya. Padahal hal ini penting di lakukan dengan benar untuk megetahui siapa yang telah melakukan pertolongan persalinan berkalitan dengan pemberian reward atau penghargaan yang di berikan terhadap penolong tersebut ataupun apabila terjadi suatu hal yang tidak baik mudah untuk di lakukan penelusurannya. Dan yang terpenting adalah sebagai bentuk tanggung jawab dalam melakukan pekerjaan dan melengkapi pendokumentasian.

Pengisian kolom urine sebesar $(29,4 \%)$ responden salah dalam mencatatkannya ke dalam partograf. Kolom ini penting untuk diisi karena untuk mengetahui output atau kecukupan cairan pada ibu bersalin serta apabila di temukan kondisi pemeriksaan laboratorium yang mengarah ke arah preeklamsia dengan hasil protein urin yang positif harus di tuliskan dengan benar dan jelas. Setiap penolong persalinan di harapkan dapat mengukur dan mencatat jumlah produksi urine setiap 2 jam (setiap ibu berkemih). Jika memungkinkan, lakukan pemeriksaan aseton dan protein dalam urine

Pencatatan penurunan kepala janin sebesar $(25,4 \%)$ responden salah dalam mengisinya, di mana dalam pengisian ke dalam partograf responden harus dapat membedakan simbol yang akan di tuliskan dalam kolom partograf sesuai dengan kasus persalinan. Tulisan "Turunnya kepala" dan garis tidak terputus dari 0-5, tertera di sisi yang sama dengan angka pembukaan serviks. Berikan tanda ' $O$ ' yang ditulis pada garis waktu yang sesuai. Sebagai contoh, jika hasil pemeriksaan palpasi kepala di atas simfisis pubis adalah 4/5 maka tuliskan tanda "O" di garis angka 4. Hubungkan tanda ' $O$ ' dari setiap pemeriksaan dengan garis tidak terputus.

Hal ini sudah sesuai dengan kompetensi yang harus di capai lulusan bidan, dimana bidan di katakan kompeten apabila penampilan keterampilan klinik mencapai $100 \%$. Kompetensi petugas pemberi pelayanan harus ditetapkan dengan tepat berdasarkan pengetahuan, keahlian, keterampilan, sikap dan perilaku yang dibutuhkan.6,10 Dalam keputusan menteri kesehatan Republik Indonesia nomor 369/Menkes/SK/III/2007 pada lampiran, ada sembilan kompetensi yang 
harus dimiliki bidan. Kompetensi yang ke empat adalah asuhan selama persalinan dan kelahiran. Bidan harus kompeten pada pengetahuan dan keterampilan dasar dalam melakukan pemantauan kemajuan persalinan dengan menggunakan partograf. (PP IBI, 2006)

Kompetensi ini diharapkan dapat diperoleh mahasiswa bidan selama pendidikan melalui pembelajaran teori, laboratorium maupun praktik klinik. Praktik klinik adalah kegiatan pembelajaran praktik dengan menggunakan target kompetensi yang harus dicapai oleh mahasiswa pada situasi nyata sesuai dengan waktu yang di jadwalkan. Pembelajaran praktik ini memberi kesempatan kepada mahasiswa mendapatkan pengalaman nyata dalam mencapai kompetensi yang dibutuhkan untuk pelaksanaan tugas- tugas tertentu. Dalam proses pembelajaran praktik mahasiswa mengembangkan tanggung jawab profesi, berpikir kritis, kreatifitas, hubungan interpersonal, pemahaman terhadap profesi, pemahaman aspek sosial budaya dan mengaplikasikan teori ke dalam praktik klinik. (Pusdiknakes Kemenkes RI, 2011).

Partograf akan memantau kemajuan persalinan dan juga membantu dalam mendeteksi dini masalah penyulit dalam persalinan. Maasalah dan penyulit dalam persalinan dapat meningkatkan morbiditas dan moralitas pada ibu dan bayi. Keterampilan pengisian partograf harus di pahami oleh semua calon bidan terutama pada saat menolong persalinan dan mengidentifikasi secara dini penyulit persalnan, dan mampu merujuk ibu bersalin tersebut secara tepat waktu dengan keputusan klinik yang benar. Dengan keterampilan pemantauan persalinan dengan partograf yang baik, partus lama dan partus macet sebagai salah satu penyebab kematian ibu dapat dicegah dan dihindari. Keterampilan yang baik pada mahasiswa yang akan lulus menjadi bidan akan sangat membantu mencegah keamtian ibu selama persalinan. Hal ini akan membantu tercapainya tujuan MDG's dalam menurunkan angka kematian ibu di Indonesia secara keseluruhan, sesuai target yang di harapkan.

\section{Gambaran Karakteristik mahasiswa}

\section{Umur}

Umur responden sebagian besar ada pada kelompok umur $\geq 20$ tahun. Hasil penelitian diperoleh sebagian besar 118 $(58,7 \%)$ responden berumur $\geq 20$ tahun. Hal ini sesuai dengan umur rata- rata saat kuliah di perguruan tinggi. Responden yang kurang terampil dalam mengisi partograf sebagian besar pada kelompok umur $\geq 20$ tahun yaitu 44,1\% di bandingkan dengan responden yang 
berumur $<20$ tahun yaitu 42,2\%. Hal tersebut tidak sesuai dengan teori diatas bahwa seseorang yang memiliki usia lebih dewasa akan lebih baik dalam keterampilannya mengingat paparan informasi dan pengalaman hidupnya.

Secara statistik variabel umur tidak bermakna atau tidak berhubungan dengan keterampilan pengisian partograf. Hal ini didasarkan pada hasil Chi square dengan $\mathrm{CI}=95 \%(\alpha=0,05)$ diperoleh $p \cdot$ value $=$ 0,902, karena p.value $>\alpha$ maka Ho diterima, dan Ha ditolak, sehingga dapat diinterpretasikan bahwa tidak ada hubungan yang signifikan Umur dengan keterampilan pengisian partograf pada mahasiswa Akademi Kebidanan di Jakarta Timur.

Notoatmodjo (2010) mengemukakan bahwa umur merupakan lama hidup yang dihitung sejak dilahirkan. Semakin bertambah umur seseorang, semakin bertambah pula data tanggapnya. Melalui perjalanan umur yang semakin dewasa individu yang bersangkutan akan melakukan adaptasi perilaku terhadap lingkungan atau semakin dewasa usia seseorang akan mudah beradaptasi dengan lingkungan.

\section{Status SMA}

Status SMA responden sesuai dengan tabel 4.4 menunjukkan sebagian besar $108(53,7 \%)$ responden berasal dari
SMA swasta di bandingkan yang berasal dari seklah SMA Negeri yaitu 46,3\%. Responden yang kurang terampil dalam mengisi partograf lebih besar terdapat pada mahasiswa yang berasal dari SMA swasta yaitu sebesar 47,2\% di bandingkan dengan responden yang berasal dari SMA Negeri yaitu 38,7\%. Hasil uji korelasi menggunakan Chi square dengan $\mathrm{CI}=$ 95\% $(\alpha=0,05)$ diperoleh $p$.value $=0,284$, karena p.value $>\alpha$ maka Ho diterima, dan Ha ditolak, sehingga dapat diinterpretasikan bahwa tidak ada hubungan yang signifikan antara status SMA dengan keterampilan pengisian partograf pada mahasiswa Akademi Kebidanan di Jakarta Timur.

Hal ini sesuai dengan teori yang mengatakan bahwa sekolah negeri secara umum memperoleh input siswa dengan prestasi hasil ujian pada jenjang pendidikan sebelumnya lebih baik dan rata-rata siswa memiliki motivasi belajar yang lebih tinggi terutama karena faktor lingkungan, kondisi sosial ekonomi dan akademik maupun fasilitas belajar dari orang tua relatif lebih baik. Keberadaan tenaga kependidikan rata-rata lebih stabil dan tingkat kompetensi maupun kesejahteraan yang lebih baik dan fasilitas pembelajaran relatif lebih baik dan lebih berkembang. 
Sekolah swasta secara umum input siswa dengan nilai rata-rata ujian akhir maupun prestasi berada di bawah siswa yang masuk sekolah negeri maupun swasta tertentu itupun untuk memperoleh siswa sesuai dengan daya tampung, kondisi sekarang cukup berat, daya dukung sosial ekonomi, akademik dan fasilitas belajar dari orang tua kurang memadai, fasilitas pembelajaran di sekolah juga kurang memadai, bahkan bisa dikatakan kurang layak, keberadaan tenaga pendidikan baik dari segi kompetensi, stabilitas, kesejahteraan masih cukup memprihatinkan.

Dari kedua hal perbedaan di atas maka dimungkinkan terdapat perbedaan prestasi akademik antara mahasiswa yang berasal dari status sekolah swasta dengan mahasiswa yang berstatus sekolah negeri.

\section{Daerah asal SMA}

Daerah asal responden menunjukan sebagian besar yaitu $63,7 \%$ responden berasal dari Jabodetabek (Jakarta, Bogor, Depok, Tanggerang, Bekasi) di bandingkan mahasiswa yang berasal dari luar Jabodetabek yaitu hanya 36,3\%. Responden yang kurang terampil dalam mengisi partograf lebih besar pada responden dengan yang asal SMAnya Luar Jabodetabek yaitu sebesar 43,8\% di bandingkan dengan responden yang berasal dari Jabodetabek yaitu $43 \%$. Hasil uji korelasi menggunakan Chi square dengan $\mathrm{CI}=95 \%(\alpha=0,05)$ diperoleh p.value $=1,000$, karena p.value $>\alpha$ maka Ho diterima, dan Ha ditolak, sehingga dapat diinterpretasikan bahwa tidak ada hubungan yang signifikan antara status SMA dengan keterampilan pengisian partograf pada mahasiswa Akademi Kebidanan di Jakarta Timur.

Hal ini dikarenakan promosi ke luar daerah memerlukan biaya yang lebih besar, sehingga tidak semua daerah mengetahui keberadaan institusi yang bersangkutan. Berbeda dengan di wilayah Jabodetabek untuk promosi sarana dan tempatnya lebih terjangkau, dan biasanya institusi kebidanan akan mudah memberikan informasi dengan mengirimkan brosur ke sekolah SMA dan biasanya orang tua akan lebih mengarahkan anaknya untuk melanjutkan kuliah dekat dengan rumah.

\section{Persepsi Proses pembelajaran}

Proses pembelajaran merupakan suatu proses interaksi antara siswa dengan pengajar dan sumber belajar dalam satu lingkungan dengan bentuk bantuan yang diberikan pengajar supaya bisa terjadi proses mendapatkan ilmu pengetahuan dan penguasaan keterampilan. Variabel persepsi proses pembelajaran dalam penelitian ini mencakup tiga sub variabel yaitu kurikulum, dosen dan evaluasi. 
Persepsi mahasiswa tentang proses pembelajaran sebagian besar $52,2 \%$ responden memiliki persepsi proses pembelajaran baik dibandingkan mahasiswa yang mempunyai persepsi proses pembelajaran tidak baik yaitu $47,8 \%$. Namun hal ini masih ada yang harus di perbaiki dalam proses pembelajaran terlihat dari jawaban responden yang menyatakan $(54,7 \%)$ tidak setuju Dosen selalu hadir tepat waktu, hal ini berarti kedisiplinan dosen dalam mengajar sering terlambat, $(41,8 \%)$ responden tidak setuju Dosen mudah di temui untuk keperluan konsultasi laporan atau materi kuliah dan $(36,3 \%)$ responden tidak setuju pembimbing praktek mudah di temui untuk keperluan konsultasi laporan atau materi praktek.

Responden yang kurang terampil mengisi partograf sebagian besar terdapat pada responden yang mempunyai persepsi proses pembelajaran tidak baik yaitu $(45,8 \%)$ daripada responden dengan persepsi proses pembelajaran baik yaitu (41,0\%). Hasil uji korelasi menggunakan Chi square dengan $\mathrm{CI}=95 \%(\alpha=0,05)$ diperoleh p.value $=0,579$ karena $p$.value $>$ a maka Ho diterima, dan Ha ditolak, sehingga dapat diinterpretasikan bahwa tidak ada hubungan yang signifikan antara persepsi proses pembelajaran dengan keterampilan pengisian partograf pada mahasiswa Akademi Kebidanan di Jakarta Timur.

Hal ini sesuai dengan teori bahwa proses akan dikatakan memiliki mutu yang tinggi apabila pengkoordinasian dan penyerasian serta pemaduan input (guru, siswa, kurikulum, uang, peralatan, dan lain-lain) dilakukan secara harmonis, sehingga mampu menciptakan situasi pembelajaran yang menyenangkan (enjoyable learning),mampu mendorong motivasi dan minat belajar, dan benarbenar mampu memberdayakan peserta didik. Kata memberdayakan mempunyai arti bahwa peserta didik tidak sekedar menguasai pengetahuan yang diajarkan oleh gurunya, namun pengetahuan yang mereka dapatkan tersebut juga telah menjadi muatan nurani peserta didik yaitu mereka mampu menghayati, mengamalkan dalam kehidupan sehari-hari, dan yang terpenting peserta didik tersebut mampu belajar secara terus menerus atau mampu mengembangkan dirinya.

Program studi harus memiliki fokus dan komitmen yang tinggi terhadap mutu penyelenggaraan proses tahap akademik dan tahap profesi (pendidikan, penelitian, dan pelayanan/pengabdian kepada masyarakat) dalam rangka memberikan kompetensi yang dibutuhkan mahasiswa untuk menjadi lulusan yang mampu 
bersaing. Standar ini juga mencakup bagaimana seharusnya program studi memperlakukan dan memberikan layanan prima kepada mahasiswa dan lulusannya, termasuk di dalamnya segala sesuatu yang berkenaan dengan upaya untuk memperoleh mahasiswa yang betrmutu tinggi melalui system dan program rekrutmen, seleksi, pemberian layanan akademik/fisik/sosial-pribadi, monitoring dan evaluasi keberhasilan mahasiswa (outcome) dalam menempuh, penelaahan kebutuhan dan kepuasan mahasiswa serta pemangku kepentingan. Dengan demikian mampu menghasilkan lulusan yang bermutu tinggi, dan memiliki kompetensi yang sesuai dengan kebutuhan dan tututan pemangku kepentingan

\section{Persepsi Fasilitas Pendidikan}

Fasilitas pendidikan adalah segala sesuatu yang dapat dipindahkan dan digunakan dalam penyelenggaraan proses akademik sebagai alat teknis dalam mencapai maksud, tujuan, dan sasaran pendidikan. Fasilitas tersebut antara lain komputer, peralatan, dan perlengkapan pembelajaran di dalam kelas, alat laboratorium dan alat kantor, serta penunjang dilingkungan akademik lainnya.

Persepsi responden terhadap fasilitas Pendidikan pada penelitian ini dibedakan atas kelompok Kurang dan Baik.
Didapatkan sebagian besar yaitu 106 $(52,7 \%)$ responden mempunyai persepsi fasilitas pendidikan baik. Hasil uji korelasi menggunakan Chi square dengan $\mathrm{CI}=$ 95\% $(\alpha=0,05)$ diperoleh $p$.value $=0,497$, karena p.value $<\alpha$ maka Ho ditolak, dan $\mathrm{Ha}$ diterima, sehingga dapat diinterpretasikan bahwa ada hubungan yang signifikan antara fasilitas dengan keterampilan pengisian partograf pada mahasiswa Akademi Kebidanan di Jakarta Timur

Persepsi responden terhadap fasilitas pendidikan berdasarkan item pertanyaan menunjukan bahwa ada responden yang berpendapat tidak setuju kemampuan koneksi internet tidak bermasalah dan stabil yaitu sebesar 56,2\% artinya koneksi internet yang ada tidak stabil dan bermasalah. Responden yang menyatakan tidak setuju kalau perpustakaan selalu menyediakan buku- buku baru sesuai dengan perkembangan teknologi kesehatan khususnya bidang kebidanan sebesar $50,7 \%$ artinya perpustakaan tidak rutin untuk menambah referensi pustaka dan bacaan yang di perlukan mahasiswa sesuai dengan perkembangan keilmuan.

Hal ini sesuai dengan teori yang mengatakan bahwa Fasilitas seringkali menjadi penghambat dalam proses belajar, fasilitas yang kurang memadai dan tidak/kurang menunjang proses belajar 
mengajar akan mengurangi minat individu untuk belajar. Fasilitas disini, khususnya untuk kegiatan perkuliahan seperti ruangan belajar yang nyaman, bangku dan meja, perpustakaan serta ruang praktikum, tempat ibadah dan kamar kecil tersedia dengan baik. Media belajar seperti bukubuku dan bahan cetakan yang disediakan di perpustakaan tersusun dengan baik dan selalu diperbaharui dan ini kan memberikan semangat kepada mahasiswa untuk selalu belajar.

\section{Motivasi}

Motivasi adalah semua kondisi yang memberi dorongan atau keadaan dalam diri seseorang yang mengaktifkan atau menggerakan seseorang untuk berbuat dan bekerjasama secara optimal melaksanakan sesuatu yang telah direncanakan untuk mencapai tujuan yang ditetapkan.

Motivasi mahasiswa dalam penelitian ini dibedakan atas kelompok rendah dan tinggi. Didapatkan bahwa sebagian besar yaitu $57,7 \%$ memiliki motivasi tinggi. Namun masih ada point yang menyatakan motivasi tersebut belum muncul dari dalam diri mahasiswa sendiri, hal ini dapat dilihat dari jawaban responden yang sebagain besar (93\%) setuju mengisi partograf saat dilihat pembimbing saja, $(89,6 \%)$ responden setuju merasa mengisi partograf hanya menambah beban tugas di lahan praktik dan $(83,1 \%)$ responden setuju dengan alasan mengisi partograf karena apabila tidak mengerjakannya diberikan sanksi dari pembimbing.

Responden yang kurang terampil mengisi partograf sebagian besar terdapat pada responden yang memiliki motivasi rendah yaitu $(55,3 \%)$ dibandingkan dengan responden yang memiliki motivasi tinggi (34,5\%). Hasil uji korelasi menggunakan Chi square dengan $\mathrm{CI}=$ 95\% $(\alpha=0,05)$ diperoleh $p$.value $=0,005$, karena p.value $<\alpha$ maka Ho ditolak, dan Ha diterima, sehingga dapat diinterpretasikan bahwa terdapat hubungan yang signifikan antara motivasi dengan keterampilan pengisian partograf pada mahasiswa Akademi Kebidanan di Jakarta Timur dan diperoleh nilai OR $(\operatorname{Exp} B)=$ 2.350 artinya mahasiswa yang memiliki motivasi tinggi cenderung lebih baik keterampilannya dalam pengisian partograf sebanyak dua kali lebih besar dibandingkan dengan mahasiswa yang memiliki motivasi rendah terhadap keterampilan pengisian partograf pada mahasiswa Akademi kebidanan di Jakarta Timur.

Namun demikian antara responden yang satu dengan yang lainnya mungkin mempunyai motivasi yang berbeda dalam melaksanakan tugasnya, hal ini sejalan dengan teori yang menyatakan bahwa 
motivasi merupakan hasil interaksi antara individu dan situasinya, sehingga setiap manusia mempunyai motivasi berbeda anatar yang satu dengan yang lainnya, motivasi sulit diukur dan diamati secara langsung, tetapi dapat diduga dari perilaku manusia. (Bekti, 2011).

Pada dasarnya motivasi merupakan daya pendorong yang menyebabkan sesorang dalam organisasi mau dan rela untuk mengerahkan kemampuannya dalam bentuk keahlian atau keterampilan, tenaga dan waktunya untuk melakukan berbagai kegiatan yang menjadi tanggung jawabnya dan sasaran organisasi. Kemampuan, kecakapan dan keterampilan mahasiswa tidak ada artinya bagi institusi pendidikan jika mahasiswa tidak mau bekerja keras dengan mempergunakan kemampuan, kecakapan dan keterampilan yang dimiliki. ( Bekti, 2011) Motivasi yang baik akan mendukung setiap individu untuk mau bekerja keras dan antusias dalam melaksanakan setiap kewajibannya dengan penuh kesadaran dan tanggung jawab.

Hasil penelitian ini sesuai dengan penelitian Ratifa (2006), bahwa ada pengaruh antara motivasi terhadap penerapan standar asuhan persalinan normal oleh bidan (Ratifa, 2006) dan sesuai juga dengan penelitian bahwa ada pengaruh antara motivasi dengan ketepatan dan kelengkapan pengisian partograf.

(Sultina, 2012). Dengan motivasi yang tepat maka akan mendorong mahasiswa untuk berbuat semaksimal mungkin melaksanakan tugasnya. (Azwar, 1996)

Menyadari akan pentingnya tugas dan tanggung jawab tersebut, seyogyanya bidan lebih profesional dalam bekerja. (Sulivan, 1997). Hal ini berarti semakin baik motivasi seorang bidan maka akan semakin baik pula kinerjanya dalam mengisi partograf dengan benar. (Siagian, 2004)

\section{SIMPULAN}

Keterampilan pengisian partograf pada mahasiswa Akademi Kebidanan di Jakarta Timur sebagian besar yaitu 56,7\% sudah baik dalam mengisi simulasi kasus ke dalam partograf dan $43,3 \%$ responden kurang dalam mengisi simulasi kasus ke dalam partograf. Variabel yang berhubungan terhadap keterampilan pengisian partograf pada mahasiswa Akademi kebidanan di Jakarta Timur adalah motivasi $(p=0,005)$ dan nilai OR $($ Exp B $)=2.350$ artinya mahasiswa yang memiliki motivasi tinggi cenderung lebih baik keterampilannya dalam pengisian partograf sebanyak dua kali lebih besar dibandingkan dengan mahasiswa yang memiliki motivasi rendah terhadap keterampilan pengisian partograf pada 
mahasiswa Akademi kebidanan di Jakarta Timur

\section{KEPUSTAKAAN}

Badan Peningkatan dan Pemberdayaan Sumber Daya Manusia (BPPSDM)

Kesehatan. Modul Pelatihan

Peningkatan Manajemen Kesehatan

Keluarga dalam Pencapaian

MDG's. Kementerian Kesehatan

RI. Jakarta. 2011.

Badan Koordinasi Keluarga Berencana Nasional (BKKBN). Survei Demografi dan Kependudukan Indonesia. Jakarta. 2012.

Salma. Lima Besar Penyebab Kematian Ibu di Indonesia. Majalah Kesehatan. Jakarta. 2012.

Kementerian Kesehatan RI. Acuan Pelatihan Asuhan Persalinan Normal. Kementerian Kesehatan RI. Jakarta. 2008.

Rury N. Konsep Kebidanan. Graha Ilmu. Yogyakarta. 2012.

Kementerian Kesehatan RI. Keputusan Menteri Kesehatan RI, Nomor 1464 tentang Izin dan Penyelenggaraan Praktik Bidan. Kementerian Kesehatan RI. Jakarta. 2010.

Kementerian Kesehatan RI. Surat keputusan Menteri Kesehatan RI Nomor 369/MENKES/SK/III/2007 tentang Standar Profesi Bidan. Kementerian Kesehatan RI. Jakarta. 2007.

Dudi Z. Etika dan Manajemen Kebidanan. Cahaya Ilmu. Yogyakarta. 2010.

Pengurus Pusat Ikatan BIdan Indonesia (PP IBI). Kompetensi Bidan Indonesia. Pengurus Pusat Ikatan BIdan Indonesia (PP IBI). Jakarta. 2006.

Kementerian Kesehatan RI. Kurikulum Inti Pendidikan Diploma III Kebidanan. Kementerian Kesehatan RI. Jakarta. 2011.

Pusat Pendidikan Tenaga Kesehatan (Pusdiknakes).

Panduan

Pembelajaran Praktik Klinik

Kebidanan dengan Pendekatan

Preceptorship dan Mentorship.

Kementerian Kesehatan RI.

Jakarta. 2011.

Pusat Pendidikan dan Pelatihan Tenaga Kesehatan (Pusdiklatnakes).

Seleksi Penerimaan Mahasiswa

Baru Diknakes. Kementerian

Kesehatan RI. Jakarta. 2012.

Sapartinah T. Panduan Belajar Soal Partograf dalam Ujian Metode Osca. Akbid Pemkab Kendal. 2011. Saifudin. Panduan Praktis Pelayanan Kesehatan Maternal dan Neonatal, Yayasan Bina Pustaka Sarwono Prawirohardjo. Jakarta. 2010. 
Kementerian Kesehatan RI. Surat keputusan Menteri Kesehatan RI Nomor

900/MENKES/SK/VII/2002

tentang Registrasi dan Praktik

Bidan. Kementerian Kesehatan RI. Jakarta. 2002.

Elfindri. Soft Skills Panduan Bagi Bidan dan Perawat. Baduose Media. Jakarta. 2009.

Notoatmodjo S. Promosi Kesehatan Teori dan Perilaku. Rhineka Cipta. Jakarta. 2010.

Notoatmodjo S. Metodologi Penelitian Kesehatan. Rhineka Cipta. 2010.

Green LW and Kreuter MW. Health Promotion Planning: an Educational and Environmental Aproach (second edition). Mayfield Publishing Company. California. 2000.

Azrul A. Pengantar Administrasi Kesehatan. Binarupa Aksara. Jakarta. 2002.

Muninjaya A. Manajemen Kesehatan. EGC. Jakarta. 2004.

Sugiyono. Statistik Untuk Penelitian. Alfabeta. Bandung. 2006.

Wahyuni Y. Metodologi Penelitian Bisnis Bidang Kesehatan. Fitramaya. Yogyakarta. 2009.

Machfoedz I. Teknik Menyusun KTISkripsi-Tesis Tulisan dalam Jurnal
Bidang Kebidanan, Keperawatan dan Kesehatan. Fitramaya. Yogyakarta. 2011.

Sayekti B. Faktor yang Berhubungan dengan Penggunaan Partograf oleh Bidan dalam Pertolongan Persalinan di Kabupaten Semarang (Tesis). Magister Ilmu Kesehatan Masyarakat Fakultas Kesehatan Masyarakat Universitas Diponegoro. Semarang. 2011.

Widiawati E. Evaluasi Penggunaan Partograf oleh Bidan Delima di Kabupaten Purworejo Provinsi Jawa Tengah (Tesis). Magister Ilmu Kesehatan Masyarakat Fakultas Kesehatan Masyarakat Universitas Diponegoro. Semarang. 2007. 